\title{
Accompaniment for Contemporary Artist in the Making of Documentary Film About Cultural Values at Kasepuhan Ciptagelar Indigenous Community
}

\author{
Nala Nandana Undiana*, Dedi Warsana \\ Film and Television Study Program \\ Universitas Pendidikan Indonesia \\ Bandung, Indonesia \\ *nalanandana@upi.edu, warsana.dedi@upi.edu
}

\author{
Arief Johari \\ Visual Communication Design Study Program \\ Universitas Pendidikan Indonesia \\ Bandung, Indonesia \\ riefjohar@gmail.com
}

\author{
Iwan Pranoto \\ Seni Drama Tari dan Musik \\ Universitas Palangka Raya \\ Palangkaraya, Indonesia \\ pranotoiwan@fkip.upr.ac.id
}

\begin{abstract}
Kasepuhan Ciptagelar indigenous community are a group of people who live within the Halimun-Salak Mountain National Park. The area is a conservation forest that has an important role in supporting global climate balance, especially in Java. This research focuses on developing the field of science that can represent the role of Yoyo Yogasmana as a contemporary artist who living in Kasepuhan Ciptagelar. The methodology used in this study is field research that describes the conditions and phenomena encountered by researchers during observation in the field. The data obtained is the result of observation, interviews with sources and physical data collection in the form of artifacts that can be documented in the field. Yoyo Yogasmana is a contemporary artist who is not from the Kasepuhan Ciptagelar indigenous community, but his role as a spokesperson for indigenous community with the outside world provide a new understanding of the life of indigenous peoples today. This research produces a documentary film that can be a new understanding related to the wisdom of local culture as the basis of noble values that are still held in high esteem. This makes Kasepuhan Ciptagelar have an adaptive mechanism to withstand the pressures of changing times.
\end{abstract} film

Keywords-indigenous community, field research, documentary

\section{INTRODUCTION}

The Kasepuhan Ciptagelar indigenous people are a group of people who live in the Mount Halimun - Salak National Park. This area is a conservation forest that has an important role in supporting the balance of the global climate, especially on the island of Java. The conservation forest in the Mount Halimun area is the largest conservation forest area on the island of Java, so we can find a variety of life in it, including the Kasepuhan Ciptagelar indigenous group [1]. Kasepuhan Ciptagelar traditional village is known to have a variety of local knowledge, this is also one of the characteristics of the preservation of local wisdom of the archipelago in Indonesia. The principles of noble values that are still upheld in it make this traditional village have an adaptive mechanism to withstand the pressures of the ever-developing times. Based on their local knowledge, indigenous peoples have their own way of seeing and connecting with the world, the universe and other people [2]. Their local knowledge plays an important role in deciding how they should connect with the universe and the outside world [3]

Indigenous peoples who are longtime or original residents in the middle of Halimun conservation forest are now becoming accessible to the outside world. It's not as we imagined, that the indigenous people living in the traditional village are not currently isolated. Basically, indigenous peoples are very open to immigrants, this is indicated by the number of study visits from educational institutions that deliberately make the visit agenda as material for academic studies. Local knowledge can be related to indigenous, traditional, unique knowledge that can live and be developed by certain community conditions [4]. Grenier also thinks that local knowledge is dynamic, so that new knowledge develops continuously and existing local knowledge will adapt new knowledge to be developed in local situations.

Of the many stories about the Kasepuhan Ciptagelar traditional village, there is an interesting figure who can be said to have an important role in the relationship between indigenous peoples and the development of the outside world. $\mathrm{He}$ is Yoyo Yogasmana, a contemporary artist who is not from 
the Kasepuhan Ciptagelar traditional village, but his role as a spokesperson for indigenous peoples with the outside world can be said to provide a new understanding of the life of indigenous peoples today.

Based on the identification of Yoyo as a contemporary artist who actively maintains noble values in the Kasepuhan Ciptagelar indigenous people. So the researcher tries to do service based on the field of science that focuses on Yoyo Yogasmana as a contemporary artist in the process of conveying the message and meaning of the noble values of the Kasepuhan Ciptagelar indigenous people in the outside world. Through this community service program, it is hoped that it can provide an overview of the important role of the artist figure in society in general. Basically, Yoyo Yogasmana has done the same thing as a contemporary art actor. He often performs performance art which broadly raises the discourse on local wisdom that exists in Ciptagelar. In the mentoring process that will be carried out this time, the researcher tries to provide a "pop" element in the documentary film that will be created. This is an effort made by researchers to further socialize the discourse of local wisdom contained in Ciptagelar. So far, discourse related to local wisdom has not become the mainstream discourse among millennials. This also causes the millennial generation to lack enthusiasm in observing the local wisdom found in Indonesia. Therefore, researchers feel the need to accompany the figure of a contemporary artist (Yoyo Yogasmana) in the process of disseminating information as a discourse for preserving local wisdom for the millennial generation.

\section{RESEARCH METHODS}

This research method is conducted using descriptive analytical and using triangulation techniques to obtain data validation. Triangulation technique is a technique used to answer the problem formulation comprehensively, namely: documentation study, interview and literature study. Method triangulation means that researchers use different data collection techniques to obtain data from the same source by means of participatory observation, structured interviews, and documentation [5].

In the context of this research, the first thing to do is observation by conducting a location survey to Kasepuhan Ciptagelar to find out a number of things that will be used as initial data, namely knowing the demographic and cultural conditions that develop as well as locations that allow for taking pictures (videos), building intimacy with the author with Kasepuhan indigenous people at the same time know the customary norms that the author should know as a guest, and conduct an early stage interview with Yoyo Yogasmana as Kasepuhan Spokesperson to get initial information as material for making interview instruments, as well as finding out who the next interview target is.

The second is to conduct an interview with Yoyo Yogasmana as a contemporary artist who has an important role in the Kasepuhan Ciptagelar traditional village which is the main focus of this assistance. Interviews were also given to the community of the Kasepuhan Ciptagelar traditional village, represented by the customary leader, namely Abah Ugi Sugriana Rakasiwi, known as the Elder Girang (Traditional Leader) of Kasepuhan Ciptagelar. In addition, interviews were also given to several Kasepuhan residents, including the mineal community, who were randomly selected to gather the required information and answer research questions.

The third is conducts a documentation study in the form of a study of the artifacts owned by Kasepuhan, both written data and image artifacts, as well as material and territorial objects that will enrich this research.

\section{RESULTS AND DISCUSSION}

Currently the Ciptagelar traditional kasepuhan is led by a traditional leader, namely Abah Ugi Sugriana Rakasiwi, known as Sesepuh Girang (Traditional Leader) of Kasepuhan Ciptagelar who is the center of the running of the government in carrying out the principle of balancing the world of reality with spirituality. All customary apparatuses in the customary institutional structure are responsible to the highest leadership, namely the Elders. All positions in the structure are based on descent, not chosen and determined by Kasepuhan residents. The exception applies to Kokolot Lembur or elders at the village level elected by the Incu Putu or Kasepuhan residents in the village concerned. Kokolot lembur are the village elders and in adat meetings it is a forum that determines when the whole series of cycles from land preparation to harvest will be held. In general, the Kokolot overtime has a certain position in the structure of the Kasepuhan customary board (see figure 1).

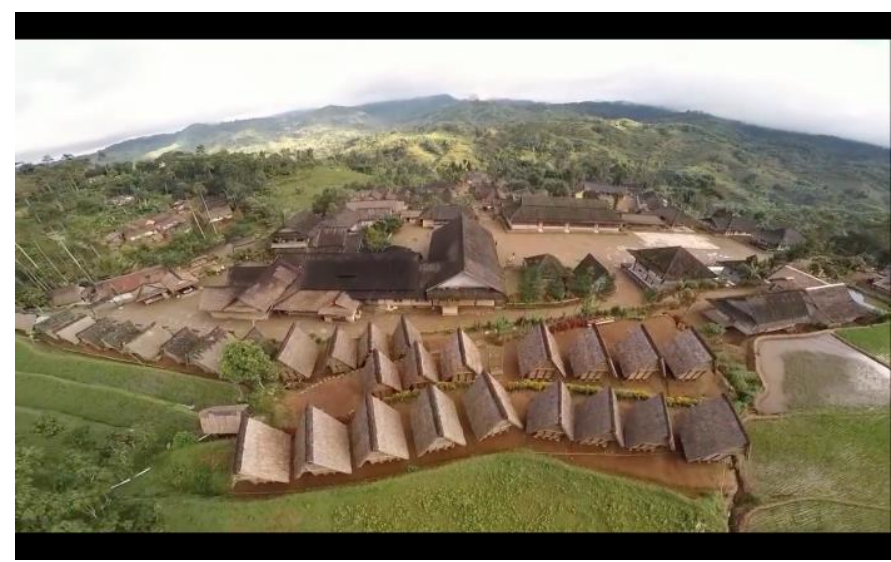

Fig. 1. Kasepuhan Ciptagelar.

Lately, many print and electronic media have carried out coverage on matters related to indigenous peoples, both raising the side of conflicts over customary land ownership rights, elevating indigenous peoples as tourist destinations, even customary villages as areas of preservation of noble culture. The Kasepuhan Ciptagelar indigenous people are no exception. Through media coverage which is currently very easy to access, it is not uncommon to invite the wider community to 
participate in witnessing what is contained in the Kasepuhan indigenous community. Traditional ceremonies are the most popular activities. So it's no wonder Hajat Lembur or village party like Seren Tahun is a kind of tourism that is most in demand by the public. This is also what makes the Ciptagelar indigenous people more and more known.

Seren Taun. Is the culmination of indigenous peoples Ciptagelar activities in the life cycle of rice. The event is held annually as part of the tradition of honoring the ancestors and the goddess of rice Sang Hyang Pohaci (Dewi Sri), the event is held as a token of gratitude for the abundant harvests with a variety of art forms including jipeng, masks, angklung, dog lojor,wayang golek This event is usually attended by the indigenous people of Banten Kidul, invitations as well as the outside community kasepuhan Ciptagelar. The main one is the rice brought by paraded forward later and stored in barns, one of them in a communal [6].

One of the traditional leaders who participated in the management of this overtime program so that it could be covered by the media and accessed by the wider community was Yoyo Yogasmana, one of the traditional leaders who held the position of spokesperson for Kasepuhan. It was his initiative that many customary activities, almost all of which aimed to uplift the noble values of Kabuyutan, were organized and accessible to interested people. On the basis of these noble values, various traditional ceremonies are informed as preservation efforts as well as practicing the principles of balance in life.

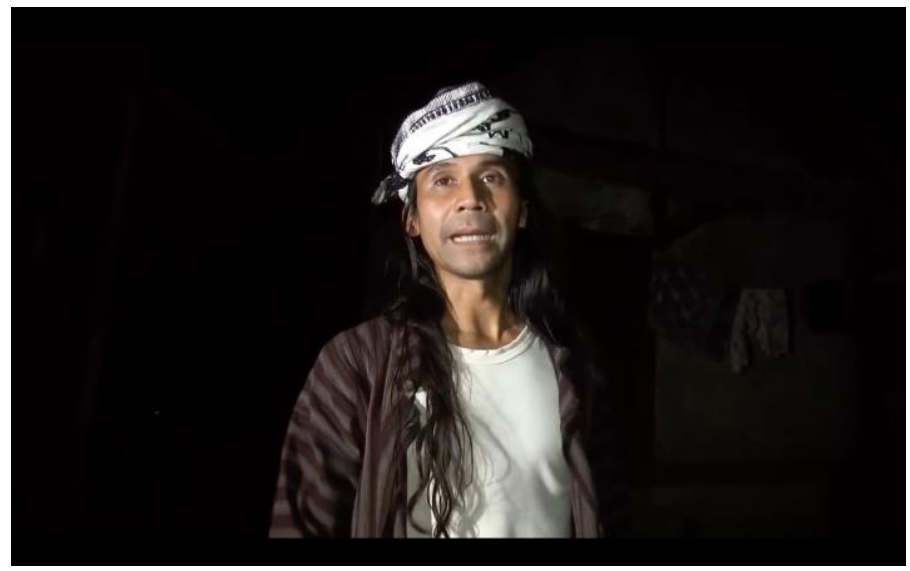

Fig. 2. Yoyo Yogasmana.

Yoyo Yogasmana (figure 2) does not come from the Kasepuhan Ciptagelar customary community, but a migrant who comes from the city of Tasikmalaya. However, the current figure of Yoyo Yogasmana is an important figure in the government system in Kasepuhan Ciptagelar. As a spokesperson, of course you must have special skills that can represent traditional villages from the perspective of the outside community. Some of his special skills make Yoyo deemed fit for his duties as a spokesperson, such as his speaking skills, having an understanding of arts and culture, broad insight, having many links and connections, and even an expert in acupuncture.

Based on interviews conducted by researchers, it is informed that Yoyo Yogasmana is a contemporary artist who often presents his works at home and abroad. Some of his Performance Art works have received a wide enthusiasm from the art public that has taken him to several countries for presentation. In fact, the art insight that led him to become a contemporary artist is not surprising, because as a person who had received higher education in the Arts and Crafts Department at IKIP Bandung in 1989 (currently IKIP Bandung changed to UPI), Yoyo was also involved and active in groups. Student Theater of IKIP Bandung (Teater Mahasiswa IKIP Bandung/TMIB) both as an actor, artistic director, and director and the choice of presenting his ideas through Performance Art has built a journey of exploration and artistic insight into a contemporary artist.

As an artist, Yoyo Yogasmana's career can be said to be very good. In addition to building an image as an artist, he has also connected him with many groups, including artists and areas of tradition. This good relationship is really very useful, especially in relation to his current position as a spokesman for the Ciptagelar indigenous people. Even though as a contemporary artist, Yoyo never forgets his identity as a Sundanese. Therefore, based on his insight into Sundanese culture, Yoyo always wants to play a role in the process of maintaining the noble cultural values of the Sundanese culture. $\mathrm{He}$ is now using the opportunity to do this while living in the Kasepuhan Ciptagelar indigenous community to continue to nurture his desire, which has now become his duty as a spokesperson, to develop a discourse that is still connected with the process of preserving the noble culture in the Kasepuhan Ciptagelar traditional village.

Yoyo Yogasmana's involvement in the government system of the Kasepuhan Ciptagelar customary community did not just happen. In an interview, Abah Ugi told that the arrival of Yoyo had been predicted by traditional elders for a long time. The elders said that someone who was not from their group was believed to come.

\section{CONCLUSION}

The ongoing mentoring program is a form of documenting Yoyo Yogasmana's daily life as a contemporary artist who lives in Kasepuhan Ciptagelar. As an outsider from the Ciptagelar community, Yoyo's position as an artist who becomes the spokesperson for the community will be very interesting if it is raised in the documentary film media.

The documentary film that is produced is a description of the perspective of a contemporary artist in processing various forms of local culture in a contemporary way. This becomes effective when faced with the perspective of the current generation. The millennial generation has characteristics that are far different from previous generations. The development of communication and information technology has made most of this generation carry out the process of independent study. 
Departing from their independent studies, perceptions will emerge in the end. Therefore, the process of disseminating upto-date and interesting information can be an independent study that has the possibility to attract the attention of the millennial generation, so that there will be an interest in the process of local cultural appreciation. In the end, understanding the meaning of local cultural appreciation will increase the love of the millennial generation in Indonesia for the culture that surrounds them.

\section{ACKNOWLEDGMENT}

The article we have submitted to the journal for review is original, has been written by the stated authors and has not been published elsewhere Also the article contains no libraries or other unlawful statements and does not contain any materials that violate any personal or proprietary rigths of any other person or entity. This paper is part of the Lecturer community service program organized by Faculty of Art and Design Education, Universitas Pendidikan Indonesia. Researchers are grateful to various parties who helped the research process, including: Yoyo Yogasmana, Community at Kasepuhan Ciptagelar, lecturers at the Film and Television
Study Program and the Faculty of Art and Design Education, Universitas Pendidikan Indonesia.

\section{REFERENCES}

[1] S. Nabilla et al., "Implikasi Putusan MK No. 35/PUU-X/2012 Terhadap Eksistensi Hutan Adat Masyarakat Kasepuhan Ciptagelar Yang Tumpang Tindih Dengan Hutan Konservasi Taman Nasional Gunung Halimun Salak,” Diponegoro Law J., vol. 6, no. 35, pp. 1-22, 2017.

[2] B. munawar Rachman, "Manusia, Alam, dan Lingkungan Hidupnya Kini,” Manusia, Alam, dan Lingkung. Hidupnya Kini, vol. 14, no. 1, p. 3, 2011.

[3] S. Gunara, "Local knowledge system in music education culture at indigenous community Kampung Naga Tasikmalaya Regency," Harmon. J. Arts Res. Educ., vol. 17, no. 1, p. 48, 2017, doi: 10.15294/harmonia.v17i1.8773.

[4] Louise Grenier, Working with Indigenous Knowledge: A Guide for Researchers | IDRC - International Development Research Centre. 1998.

[5] P. R. A. Fakhruddin, "Pemenuhan Kebutuhan Belajar Anak Jalanan Di Kota Semarang Melalui Program Pendidikan Nonformal," J. Eksistensi Pendidik. Luar Sekol., vol. 2, no. 1, pp. 24-29, 2017, doi: 10.30870/eplus.v2i1.2945.

[6] S. Komariah, "Local Wisdom of Ciptagelar Community in Managing Environmental Sustainability,” 2016, doi: 10.2991/icse-15.2016.39. 